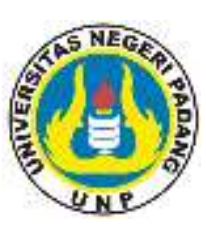

\title{
EFEKTIVITAS MEDIA LAGU BAHASA JEPANG TERHADAP PENGUASAAN GOI SISWA KELAS X SMAN 5 PADANG
}

\section{Maretta Pertalola ${ }^{1}$, Nova Yulia ${ }^{2}$}

Program Studi Pendidikan Bahasa Jepang ${ }^{1}$ (Jurusan Bahasa dan Sastra Inggris, Fakultas Bahasa dan Seni, Universitas Negeri Padang)

Program Studi Pendidikan Bahasa Jepang ${ }^{2}$ (Jurusan Bahasa dan Sastra Inggris, Fakultas Bahasa dan Seni, Universitas Negeri Padang)

Email Penulis : marettapertalola.mp@gmail.com

\begin{tabular}{ll}
\hline \multicolumn{3}{l}{ Sejarah Artikel } \\
\hline Submit $\quad: 2019-08-12$ \\
Diterima $:$ 2019-08-19 \\
Diterbitkan : 2019-12-15
\end{tabular}

Kata Kunci:

Effectiveness, japanese song media, mastery of goi.

\begin{abstract}
Abstrak
This study discusses the goi mastery of grade $X$ students in SMAN 5 Padang. The aim of this study was to find out the goi mastery of grade $\mathrm{X}$ students in SMAN 5 Padang. This reseach is quantitative research which the samples were the students of X IPA 2 as experiment class and $\mathrm{x}$ IPA 3 as control class consisting of 35 students for each class. The data in this study are done by using the grade X students' scores of the vocabulary test results. Based on the results of data analysis in this research, it can be concluded that the goi mastery of grade $\mathrm{X}$ students in SMAN 5 Padang by using Japenese song media is categorized in good qualifications with 80.68 as the average score. Meanwhile their mastery of goi without using Japanese song media is in more than adequate qualifications with 74 as the average score. Based on the results of hypothesis testing, it is concluded that there is a significant effectiveness and use of Japanese song media on goi mastery of grade $\mathrm{X}$ students of SMAN 5 Padang because of the value of $t_{\text {hitung }}>t_{\text {tabel }}$ $(6,07>1,66)$.
\end{abstract}

\section{PENDAHULUAN}

Bahasa merupakan alat komunikasi yang digunakan oleh manusia untuk berinteraksi melalui kata-kata maupun gerak tubuh. Sudjianto dan Dahidi (2009:1) menyatakan bahwa istilah bahasa Indonesia sangat netral, dapat dipakai dalam berbagai konteks, dipakai oleh siapa saja, kepada siapa saja, dan dalam kajian apa saja baik sebagai bahasa pertama, bahasa kedua, dan seterusnya atau sebagai bahasa asing. Hal ini berbeda dengan istilah "bahasa Jepang" di dalam bahasa Jepang disebut nihongo tetapi ada juga yang menyebutnya kokugo. Kakugo adalah bahasa resmi warga negara (Jepang) yang lahir dan hidup di suatu negara yang sama. Istilah kakugo sering dipakai oleh orang Jepang untuk menyatakan bahasanya sendiri sebagai bahasa ibu. Sedangkan nihongo adalah bahasa Jepang yang dipakai sebagai bahasa asing atau sebagai bahasa kedua, bahasa ketiga, dan

${ }^{1}$ Mahasiswa Prodi Pendidikan Bahasa Jepang FBS UNP lulus pada September 2019

2 Dosen Prodi Pendidikan Bahasa Jepang FBS UNP 
seterusnya.

Dalam mempelajari suatu bahasa, ada beberapa unsur-unsur penting dalam kebahasaan yang harus dikuasai oleh pembelajar. Diantaranya adalah huruf, kosakata, tata bunyi dan struktur kalimat. Salah satu unsur yang penting adalah kosakata. Menurut Nasution (2018) menyatakan bahwa kosakata merupakan aspek yang penting dalam pembelajaran bahasa. Keterampilan berbahasa yang terdiri dari menyimak, berbicara, membaca dan menulis akan diperoleh apabila menguasai kosakata. Tak terkecuali dalam mempelajari bahasa Jepang. Tarigan (2011:2) menyatakan bahwa kualitas keterampilan berbahasa seseorang bergantung kepada kuntitas dan kualitas kosakata yang dimilikinya. Semakin kaya kosakata yang kita miliki, semakin besar pula kemungkinan kita terampil berbahasa. Begitu juga dalam mempelajari bahasa Jepang. Dalam Kamus Besar Bahasa Indonesia (2008:736) menyebutkan kosakata adalah pembendaharaan kata. Kosakata dalam bahasa Jepang disebut goi.

Menurut Machi (dalam Sudjianto dan Dahidi, 2009:97) goi dapat didefenisikan sebagai go no mure atau go no atsumari „kumpulan katae. Sedangkan Takamizawa (2004:139) menyatakan bahwa goi merupakan go no shuugou ,seperangkat kata-katae ${ }^{e}$. Shinmura (dalam Sudjianto dan Dahidi, 2009:97) menyebutkan goi adalah keseluruhan kata (tango) berkenaan dengan suatu bahasa atau bidang tertentu yang ada di dalamnya. Salah satu aspek kebahasaan yang harus diperhatikan dan dikuasai untuk menunjang kemampuan berkomunikasi dalam bahasa Jepang secara lisan maupun tulisan.

SMAN 5 Padang merupakan salah satu sekolah yang sudah memiliki pembelajaran bahasa Jepang, dimana bahasa Jepang dijadikan salah satu pelajaran lintas minat. Berdasarkan pengamatan pada saat observasi di SMAN 5 Padang selama melakukan Praktik Lapangan Kependidikan, diperoleh informasi bahwa hampir rata-rata siswa kesulitan dalam menguasai goi. Selain itu media pembelajaran yang kurang menarik dan bervariasi menyebabkan siswa jenuh dan kurang bersemangat.

Salah satu cara yang digunakan untuk mengatasi hambatan di atas adalah menggunakan media pembelajaran. Media pembelajaran sangatlah penting, maka dari itu penulis mencoba mencari pemecahan masalah yang ada pada penguasaan goi, menggunakan media lagu salah satu alternatif untuk memotivasi siswa dalam membantu menguasai goi.

Nggiri (2014) dalam skripsinya yang berjudul "Keefektifan Penggunaan Media Lagu Terhadap Penguasaan Kosakata Bahasa Jerman Peserta didik Kelas X SMA Negeri 1 Muntilan Manggelang" menyimpulkan bahwa penggunaan media lagu efektif dalam meningkatkan keterampilan meningkatkan kosakata bahasa Jerman. Senada dengan itu, penelitian sejenis juga dilakukan oleh Kumalasari (2011) dalam skripsinya yang berjudul "Efektivitas Media Lagu dalam Meningkatkan Penguasaan Hiragana Siswa Kelas X SMA Negeri 1 Temanggung" menyimpulkan bahwa penggunaan media lagu efektif dalam meningkatkan penguasaan hiragana pada peserta didik kelas X SMA Negeri 1 Temanggung. Menurut penelitian yang dilakukan oleh Tito (2016) dengan judul "Efektivitas Penggunaan Media Lagu Berbahasa Jepang Pada Pembelajaran Kosakata Dalam Bahasa Jepang” penggunaan media lagu efektif dalam meningkatkan pembelajaran 
kosakata bahasa Jepang.

Media lagu dapat dijadikan alat bantu untuk berbagai macam keterampilan berbahasa. Media lagu dapat digunakan sebagai salah satu cara untuk mencapai tujuan pembelajaran yang diinginkan seperti dalam penguasaan kosakata, karena lagu dapat menarik perhatian siswa dalam proses pembelajaran sehingga memberi motivasi untuk belajar.

Lagu berperan sebagai pembangkit fungsi ingatan karena dapat membangkitkan sejarah pengalaman hidup seseorang. Jika seseorang mendengar lagu tertentu ia akan teringat tempat lagu tersebut pernah didengar. Hal ini menunjukkan bahwa fungsi ingatannya bekerja akibat adanya dampak isyarat kontekstual. Jadi, menggunakan media lagu dapat membantu siswa dalam mengingat kosakata yang dipelajari. Manfaat menggunakan media lagu bagi guru yaitu guru akan lebih bervariatif dalam proses pembelajaran. Sedangkan, manfaat untuk siswa yaitu media lagu mudah dihafal dan mudah dipahami dan siswa juga merasa senang dalam belajar. Lagu yang digunakan dalam penelitian adalah lagu bahasa Jepang dalam buku Nihongo Kira Kira Jilid 1 mengenai hari, angka dan tanggal. Hari, angka dan tanggal termasuk hal penting yang harus diketahui karena berhubungan dengan kehidupan sehari-hari. Lagu bahasa Jepang merupakan lagu yang di dalamnya menggunakan lirik bahasa Jepang.

Tujuan penelitian dalam penelitian ini, yaitu. Pertama, mendeskripsikan penguasaan goi siswa kelas X SMAN 05 Padang tanpa menggunakan media lagu. Kedua, mendeskripsikan penguasaan goi siswa kelas X SMAN 5 Padang menggunakan media lagu. Ketiga, mendeskripsikan efektivitas media lagu bahasa Jepang terhadap penguasaan goi siswa kelas X SMAN 5 Padang.

\section{METODE PENELITIAN}

Jenis penelitian ini merupakan penelitian kuantitatif, dengan metode eksperimen untuk menguji efektivitas media lagu bahasa Jepang dalam penguasaan goi. Jenis eksperimen ini adalah quasi eksperimen. Rancangan mempunyai kelas kontrol, tetapi tidak dapat berfungsi sepenuhnya untuk mengontrol variabel-variabel luar yang mempengaruhi pelaksanaan eksperimen (Sugiyono, 2015:114). Desain eksperimen yang digunakan dalam penelitian ini adalah posttest only control group design. Data dari penelitian ini adalah skor tes kemampuan kosakata siswa kelas X SMAN 05 Padang. Sampel dipenelitian ini diambil sebanyak dua kelas yaitu X IPA 2 sebagai kelas eksperimen dan X IPA 3 sebagai kelas kontrol. Sedangkan sumber data yang diambil adalah buku teks Nihongo Kira Kira jilid 1 mengenai angka, tanggal dan hari pada Bab 1, Bab 3 dan Bab 7.

Instrumen dalam penelitian ini adalah soal objektif berbentuk pilihan ganda

untuk mengukur kemampuan kosakata. Instrumen penelitian adalah tes kemampuan kosakata. Instrumen yang digunakan dalam penelitian ini adalah tes. Tes merupakan sereretan pertanyaan, atau latihan untuk mengukur keterampilan, pengetahuan, atau bakat yang dimiliki oleh individu atau kelompok (Arikunto, 2010:193).

Adapun teknik pengumpulan data sebagai berikut. Pertama, Guru memberikan pelajaran goi menggunakan media lagu pada kelas eksperimen dan 
memberikan pelajaran goi tanpa media lagu pada kelas kontrol. Kedua, Guru memberikan tes akhir (posttest). Selanjutnya guru memberi skor hasil tes penguasaan goi berdasarkan indikator yang telah ditetapkan. Kemudian dilanjutkan dengan menganalisis data dengan langkah sebagai berikut. Pertama, menentukan nilai rata-rata hitung penguasaan goi siswa kelas X SMAN 05 Padang. Kedua, mengklasifikasikan penguasaan goi dengan konversi nilai ke sistem penilaian. Ketiga, mengklasifikasikan data berdasarkan indikator. Keempat, melakukan uji hipotesis. Kelima, melakukan pembahasan. Keenam, menarik kesimpulan.

\section{HASIL DAN PEMBAHASAN}

\section{Temuan Penelitian}

Berdasarkan analisis terhadap skor tes, kemampuan penguasaan goi kelas X SMAN 5 Padang.

Table 1 Tabel Nilai Rata-Rata dan Simpangan Baku Hasil Penguasaan Goi Siswa Kelas X SMAN 5 Padang

\begin{tabular}{|l|c|c|c|c|}
\hline & Nilai Max & Nilai Min & Rata-Rata (M) & $\begin{array}{c}\text { Standar } \\
\text { Deviasi }\end{array}$ \\
\hline Eksperimen & 100 & 50 & 80,68 & 11,96 \\
\hline Kontrol & 90 & 53 & 74 & 9,99 \\
\hline
\end{tabular}

Berdasarkan tabel di atas dapat diketahui:

Pertama, diketahui nilai rata-rata penguasaan goi siswa kelas X SMAN 5 Padang tanpa menggunakan media lagu bahasa Jepang berada pada kualifikasi lebih dari cukup dengan rata-rata 74. Lalu standar deviasi yang diperoleh dari penguasaan goi siswa kelas X SMAN 5 Padang tanpa menggunakan media lagu bahasa Jepang secara keseluruhan adalah 9,99 yang berarti jarak antar nilai mahasiswa tidak terlalu jauh dan penyebaran nilai cukup beragam.

Kedua, diketahui nilai-nilai rata-rata penguasaan goi siswa kelas X SMAN 5 Padang menggunakan media lagu bahasa Jepang berada pada kualifikasi baik dengan rata-rata 80,68. Lalu standar deviasi yang diperoleh dari penguasaan goi siswa kelas $\mathrm{X}$ SMAN 5 Padang menggunakan media lagu bahasa Jepang secara keseluruhan 11,96 yang berarti jarak antar nilai mahasiswa tidak terlalu jauh dan penyebaran nilai cukup beragam.

Penguasaan goi siswa kelas X SMAN 5 Padang tanpa menggunakan media lagu per indikator, yaitu. Pertama, untuk indikator 1 nilai rata-rata hitung yang diperoleh 81,47 berada pada kualifikasi baik. Kedua, untuk indikator 2 diperoleh nilai rata-rata hitung 74,571 berada pada kualifikasi lebih dari cukup. Ketiga, untuk indikator 3 diperoleh nilai rata-rata hitung 66,28 berada pada kualifikasi lebih dari cukup.

Penguasaan goi siswa kelas X SMAN 5 Padang menggunakan media lagu per indikator, yaitu. Pertama, indikator 1 diperoleh nilai rata-rata 88,85 pada kualifikasi baik sekali. Kedua, indikator 2 diperoleh nilai rata-rata 79,71 pada kualifikasi baik. Ketiga, indikator 3 diperoleh nilai rata-rata 72,85 pada kualifikasi lebih dari cukup. 
Demikian juga dengan dengan uji hipotesis yang dilakukan $t_{\text {hhitung }}>t_{\text {tabel }}(6,07>1,66)$ pada taraf signifikan $0,05 \%$.

\section{Pembahasan}

1. Penguasaan goi kelas kelas X SMAN 5 Padang tanpa menggunakan media lagubahasa Jepang.

Berdasarkan analisis data, nilai rata-rata penguasaan goi siswa kelas $\mathrm{X}$ SMAN 5 Padang tanpa menggunakan media lagu bahasa Jepang secara umum pada kualifikasi lebih dari cukup dengan rata-rata 74. Penguasaan goi siswa kelas X SMAN 5 Padang tanpa menggunakan media lagu bahasa Jepang dilakukan dengan analisis per indikator. Pertama, indikator 1 diperoleh nilai rata-rata 81,71 pada kualifikasi baik. Kedua, indikator 2 diperoleh nilai rata-rata 74,57 pada kualifikasi lebih dari cukup. Ketiga, indikator 3 diperoleh nilai rata-rata 66,28 pada kualifikasi lebih dari cukup. Dapat disimpulkan bahwa kemampuan siswadalam penguasaan goi belum cukup memuaskan.

2. Penguasaan goi kelas X SMAN 5 Padang menggunakan media lagu bahasaJepang.

Berdasarkan analisis data, nilai rata-rata penguasaan goi siswa kelas $\mathrm{X}$ SMAN 5 Padang menggunakan media lagu bahasa Jepang secara umum pada kualifikasi baik dengan rata-rata 80,68. Penguasaan goi siswa kelas X SMAN 5 Padang di lakukan dengan analisis per indikator. Pertama, indikator 1 diperoleh nilai rata-rata 88,85 pada kualifikasi baik sekali. Kedua, indikator 2 diperoleh nilai rata-rata 79,71 pada kualifikasi baik. Ketiga, indikator 3 diperoleh nilai rata-rata 72,85 pada kualifikasi lebih dari cukup. Dapat disimpulkan bahwa kemampuan siswa dalam penguasaan goi cukup memuaskan. Jika dibandingkan nilai rata-rata kelas kontrol dan kelas eksperimen terjadi peningkatan yang cukup signifikan terhadap kelas eksperimen.

3. Efektivitas media lagu bahasa Jepang terhadap penguasaan goi siswa kelas XSMAN 5 Padang

Berdasarkan hasil pengamatan saat proses pembelajaran, penggunaan media lagu bahasa Jepang dapat membuat siswa lebih semangat dan minat dalam belajar. Siswa lebih aktif dan antusias menyanyikan lagu bahasa Jepang. Dengan menyanyikan lagu siswa dengan sendirinya dapat menghafal kosakata yang telah dinyanyikan.

Dilihat dari hasil tes penguasaan goi siswa kelas X SMAN 5 Padang dengan menggunakan media lagu bahasa Jepang dalam pembelajaran lebih tinggi dari pada hasil tes penguasaan goi siswa kelas X SMAN 5 Padang tanpa menggunakan media lagu bahasa Jepang. Hal ini dibuktikan dengan penguasaan goi menggunakan media 
lagu bahasa Jepang siswa kelas X SMAN 5 Padang secara umum berada pada kualifikasi baik dengan rata-rata 80,68. Sedangkan penguasaan goi tanpa menggunakan media lagu bahasa Jepang siswa kelas X SMAN 5 Padang secara umum berada pada kualifikasi lebih dari cukup dengan rata-rata 74 . Demikian juga dengan dengan uji hipotesis yang dilakukan $t_{\text {hhitung }}>t_{\text {tabel }}(6,07>1,66)$ pada taraf signifikan $0,05 \%$.

Dengan demikian, dapat disimpulkan bahwa penggunaan media lagu bahasa Jepang berpengaruh cukup signifikan terhadap penguasaan goi siswa kelas X SMAN 05 Padang.

\section{KESIMPULAN}

Berdasarkan hasil analis data dan pembahasan pada Bab IV, dapat disimpulkan bahwa. Pertama, penguasaan goi siswa kelas X SMAN 5 Padang dengan menggunakan media lagu bahasa Jepang berada pada kualifikasi baik dengan rata-rata 80,68,. Kedua, penguasaan goi siswa kelas X SMAN 05 Padang tanpa menggunakan media lagu bahasa Jepang berada pada kualifikasi lebih dari cukup dengan rata-rata 74. Ketiga, penguasaan goi siswa kelas X SMAN 5 Padang tanpa menggunakan media lagu per indikator. Indikator 1 diperoleh nilai rata-rata 81,71 pada kualifikasi baik. Indikator 2 diperoleh nilai rata-rata 74,57 pada kualifikasi lebih dari cukup. Indikator 3 diperoleh nilai rata-rata 66,28 pada kualifikasi lebih dari cukup. Sedangkan, penguasaan goi siswa kelas X SMAN 5 Padang dengan menggunakan media lagu per indikator. indikator 1 diperoleh nilai rata-rata 88,85 pada kualifikasi baik sekali. Indikator 2 diperoleh nilai rata-rata 79,71 pada kualifikasi baik. Indikator 3 diperoleh nilai rata-rata 72,85 pada kualifikasi lebih dari cukup.

Berdasarkan hasil uji hipotesis, disimpulkan bahwa terdapat efektivitas yang signifikan dari penggunaan media lagu bahasa Jepang terhadap penguasaan goi siswa kelas X SMAN 05 Padang karena nilai $t_{\text {hitung }}>\mathrm{t}_{\text {tabel }}(6,07>1,66)$.

\section{REFERENSI}

Abdurrahman dan Elya Ratna. 2003. Evaluasi dan Pembelajaran Bahasa dan Sastra Indonesia. Padang: Jurusan Bahasa dan Sastra Indonesia FBS UNP.

Arikunto, Suharsimi. 2010. Prosedur Penelitian Suatu Pendekatan Praktik. Jakarta: Rineka Cipta.

Djiwandono, Soenardi. 2011. Tes Bahasa. Jakarta: Indeks.

Emzir. 2008, Metodologi Penelitian Pendidikan. Jakarta: Rajawali Pers. Grimonia, Eya. 2014. Dunia Musik. Bandung: Nuansa Cendikia.

Kumalasari, Novi Deriska. 2011. "Efektivitas Media Lagu dalam meningkatkan Penguasaan Hiragana Siswa Kelas X SMA Negeri 1 Temanggung". Skripsi. Fakultas Bahasa dan Seni. Universitas Negeri Semarang. 
Lusiana, Evi dkk. 2017. Nihongo Kira Kira. Jakarta: Erlangga

Nasution, Talia Oktaviana Sari, Siti Fatimah, Nova Yulia. "Hubungan Menonton Anime dengan Kosakata (Goi) Mahasiswa Kelas XII IPS SMA Negeri 12 Padang Tahun Ajaran 2017/2018". Jurnal Omiyage vol 1 no 1. Hal 1.

Nggri, Ardityati May. 2014. "Keefektifan Penggunaan Media Lagu Terhadap Penguasaan Kosakata Bahasa Jerman Peserta Didik Kelas X SMA Negeri 1 Muntilang Magelang”. Skripsi. Fakultas Bahasa dan Seni. UniversitasNegeri Yogyakarta.

Pusat Bahasa. 2008. Kamus Besar Bahasa Indonesia. Jakarta: Gramedia. Sadiman, Arif S dkk. 2014. Media Pendidikan. Jakarta: Rajawali Pers.

Setiyadi, Bambang. 2006. Metode Penelitian untuk Pengajaran Bahasa Asing.Yogyakarta: Graha Ilmu.

Sudjana. 2005. Metode Statiska. Bandung: Tarsito

Sudjana, Nana dan Ahmad Rivai. 2015. Media Pengajaran. Bandung: Sinar Baru Algensindo.

Sudjianto. 2010. Metodologi Pembelajaran Keterampilan Bahasa Jepang. Bekasi: Kesaint Blanc.

Sudjianto dan Ahmad Dahidi. 2009. Pengantar Linguistik Bahasa Jepang. Jakarta: Kesaint Blanc.

Sugiyono. 2015. Metode Penelitian Pendidikan. Bandung: Alfabeta.

Sutedi, Dedi. 2011. Penelitian Pendidikan Bahasa Jepang. Bandung: Humaniora.

Takamizawa, Akira. 2004. Hajimeteno Nihongo Kyouiku. Jepang: JapanFoundation.

Tarigan, Henry Guntur. 2011. Pengajaran Kosakata. Bandung: Angkasa.

Tito, Reza Muhammad. 2016. "Efektivitas Penggunaan Media Lagu Berbahasa Jepang Pada Pembelajaran Kosakata Dalam Bahasa Jepang”. Skripsi. Fakultas Pendidikan Bahasa dan Sastra.Universitas Pendidikan Indonesia.

Zalman, Hendri. 2014. Kosakata Bahasa Jepang Dasar. Padang: FBS UNP Press. 